\title{
KONKURENCINİ PRANAŠUMĄ LEMIANTYS VEIKSNIAI IR INTERNACIONALIZACIJA: SĄSAJŲ TYRIMAS
}

\author{
Renata Korsakienè \\ Vilniaus Gedimino technikos universitetas, Saulètekio al. 11, LT-10223 Vilnius, Lietuva \\ El.paštas renata.korsakiene@vgtu.lt
}

Iteikta 2012-05-21; priimta 2012-09-28

\begin{abstract}
Santrauka. Globalizacija, technologiniai pokyčiai, intensyvi konkurencija, svyruojanti vartotojų paklausa, ekonominiai ir politiniai pokyčiai skatina vadovus veikti proaktyviai, prisiimti didesnę riziką ir pasirinkti tinkamas strategijas. Pažymėtina, kad tiek strateginio valdymo teoretikai, tiek praktikai savo darbuose daug dėmesio skyre įmonès konkurenciniam pranašumui ir jo išlaikymui. Kita vertus, ėmé formuotis nuomonė, kad tokie rezultatai pasiekiami gana retai ir jiems būdingas trumpalaikiškumas. Kai kuriose pramonès šakose ar verslo sektoriuose itin nuožmi konkurencija ir greiti technologiniai pokyčiai neigiamai veikia konkurencini pranašumą. Vis dèlto įmonei augant savo šalies rinkoje formuojasi internacionalizacijos strategijų igyvendinimo prielaidos. Tačiau pasirinkusios vieną ar kitą internacionalizacijos būdą, įmonès skiriasi savo pasiektais rezultatais. Todèl tikslinga kelti klausimus kodèl vienos įmonès yra sẻkmingesnès už kitas tarptautinėse rinkose. Straipsnyje nagrinėjamos konkurencinị pranašumą lemiančių veiksnių, internacionalizacijos ir prioritetinių strateginių sprendimų sąsajos, pateikiamos rekomendacijos tolesniems tyrimams.
\end{abstract}

Reikšminiai žodžiai: internacionalizacija, ilgalaikis konkurencinis pranašumas, trumpalaikis konkurencinis pranašumas, strateginiai sprendimai, sąsajos.

\section{DETERMINANTS OF COMPETITIVE ADVANTAGE AND INTERNATIONALIZATION: INVESTIGATION OF INTERRELATIONSHIPS}

\author{
Renata Korsakienè
}

\author{
Vilnius Gediminas Technical University, Saulètekio al. 11, LT-10223 Vilnius, Lithuania \\ E-mail: renata.korsakiene@vgtu.lt
}

Received 21 May 2012; accepted 28 September 2012

\begin{abstract}
Globalization, technological change, intense competition, fluctuating consumer demand and economic and political changes encourage managers to act proactively, take greater risks and to select appropriate strategies. It should be noted that both the strategic management theorists and practitioners in their works have focused on the firm's competitive advantage and its maintenance. On the other hand, the opinion that such results can be obtained relatively rarely and they are short- termed has been proposed. In some industries or business sectors competitive advantage is impacted by fierce competition and rapid technological change. However, the growth of the firm domestically forms preconditions to select internationalization strategies. However, firms, selecting different modes of internationalization, differ in their performance. Therefore, it is appropriate to raise the questions: why some firms are more successful than others in international markets. The paper investigates the interrelationships of the determinants of competitive advantage, internationalization and strategic decisions and provides recommendations for further research.
\end{abstract}

Keywords: internationalization, sustainable competitive advantage, temporary competitive advantage, strategic decisions, interrelationships.

JEL Classification: M10, M13, M19. 


\section{1. İvadas}

Globalizacija, technologiniai pokyčiai, intensyvi konkurencija, svyruojanti vartotojų paklausa, ekonominiai ir politiniai pokyčiai skatina vadovus veikti proaktyviai, prisiimti didesnę riziką ir pasirinkti tinkamas strategijas. Pažymetina, kad tiek strateginio valdymo teoretikai, tiek praktikai savo darbuose daug dèmesio skyrè konkurenciniam įmonès pranašumui ir jo išlaikymui. Artimose mokslo srityse, kaip antai ekonomika, vykdyti moksliniai tyrimai leido tvirtinti, kad egzistuoja ilgalaikio pranašumo išlaikymo prielaidos, nes daugumos įmonių rezultatams krypstant vidutinių link, kai kurioms įmonèms pavyksta pasipriešinti šiai tendencijai. Kita vertus, èmé formuotis nuomonè, kad tokie rezultatai pasiekiami gana retai ir jiems būdingas trumpalaikiškumas. Kai kuriose pramonès šakose ar verslo sektoriuose itin nuožmi konkurencija bei greiti technologiniai pokyčiai neigiamai veikia konkurencini pranašumą. Be to, laikomasi nuomonès, kad ankstesniuose tyrimuose identifikuotos ilgalaikị pranašumą turinčios imonès, tikètina, buvo daug pasiekusios trumpalaikiu pranašumų laiko atžvilgiu. Vis dèlto įmonei augant savo šalies rinkoje formuojasi prielaidos ịgyvendinti internacionalizacijos strategijas. Tačiau pasirinkusios vieną ar kitą internacionalizacijos būdą, įmonès skiriasi savo pasiektais rezultatais. Todèl tikslinga klausti - kodèl vienos įmonès yra sèkmingesnès už kitas tarptautinèse rinkose ir nagrinèti konkurencinio pranašumo, internacionalizacijos ir prioritetinių strateginių sprendimų sąsajas.

Tyrimo objektas - konkurencinis pranašumas, tiek ilgalaikis, tiek trumpalaikis, jị lemiantys veiksniai ir sąsajos su internacionalizacijos teorijomis.

Straipsnio tikslas - nustatyti konkurencinị pranašumą lemiančių veiksnių ir internacionalizacijos sąsajas.

Tyrimo metodai - mokslinès literatūros strateginio valdymo ir internacionalizacijos klausimais analizè bei sintezè.

\section{Konkurencinio pranašumo koncepcija}

Konkurencinio pranašumo koncepcija pradèjo formuotis septintajame dešimtmetyje. Mokslinèje literatūroje dažnai keliami klausimai: kodèl kai kurios i̇monès igyja pranašumą prieš kitas, kur slypi pranašumas ir kodèl išlieka, kaip jis paveikia įmonès rezultatus laiko atžvilgiu? South (1980) nuomone, strateginio valdymo procesas ir konkurencinio pranašumo valdymas leidžia identifikuoti specifines, uždaras įmonių grupes bei plètoti konkurencinị pranašumą, kuris padeda užtikrinti verslo darną. Tačiau konkurencinio pranašumo sąvoka iš tiesų tapo populiari tik dèl Porter $(1980,1985)$ darbų strateginio valdymo srityje. Porter (1985) teigimu, konkurencini pranašumą formuoja įmonès gebejjimas sukurti pirkejjui pridètinę vertę, kuri pranoksta įmonès patiriamas produkto ar paslaugos sukūrimo sąnaudas. Laikantis šio požiūrio galima teigti, kad įmonè pasiekia geriausių rezultatų tik tuomet, jei gali pateikti produktus ar paslaugas, už kurias vartotojai yra pasiruošę mokèti daugiau, nei jų sukūrimas, o vertès vartotojui sukūrimas siejamas su bet kuria sèkminga įmonès strategija. Savo ruožtu konkurencinis pranašumas parodo vadovams, kaip ịvertinti savo konkurencinę poziciją bei, siekiant ją pagerinti, igyvendinti tinkamus veiksmus (Korsakienè 2004; Ginevičius, Korsakienè 2005). Tokios koncepcijos laikydamasis Karnani (1984) pasiūlè modelį, įrodantị, kad konkurencinị pranašumą lemia sąnaudos ir diferenciacija.

Day ir Wensley (1988) nuomone, konkurencinis pranašumas yra kompleksiškas konstruktas, sudarytas iš daugelio sudedamụjų dalių ir dèl šios priežasties nèra vienos bendros „konkurencinio pranašumo“ koncepcijos (1988:2). Autorių nuomone, išsamus apibrěžimas turi apibūdinti ne tik konkurencinio pranašumo būseną, bet ir kaip konkurencinis pranašumas buvo pasiektas. Todèl konkurencinis pranašumas apima tiek pozicinį, tiek rezultatų pranašumą, kurį lemia santykinis konkurentų atžvilgiu verslo turimų ir paskirstomų gebejjimų bei išteklių pranašumas. Šie gebejimai ir ištekliai sukuria pozicinị sąnaudų ir diferenciacijos pranašumą. Tad konkurencinis pranašumas apibūdinamas kaip reikšmingas pranašumas prieš konkurentus dèl sąnau$\mathrm{duc}$, diferenciacijos ir (arba) rezultatų, kuriuos veikia pozicionavimo strategijos. Todèl neatsitiktinai teigiama, kad konkurencinio pranašumo tyrimai formuoja strateginio valdymo tyrimų esmę. Neatsitiktinai pastaraisiais dešimtmečiais formavosi skirtingi teoriniai požiūriai, siekiantys paaiškinti aplinkybes, kuriomis įmonè gali įgyvendinti konkurencini pranašumą konkurentų atžvilgiu. Mokslininkų grupès akcentuoja sandorių ir tarpininkavimo sąnaudų minimizavimą (Coase 1937; Jensen, Meckling 1976; Williamson 1975, 1985), išskirtinès konkurencinès pozicijos siekimą (Bain 1956, 1959; Porter 1980, 1985), išskirtinių strateginių išteklių plètojimą ir ịsigijimą (Amit, Schoemaker 1993; Barney 1986, 1991; Peteraf 1993; Wernerfelt 1984), gebejiimą naujai konfigūruoti išteklius ị naujus strategiškai vertingus derinius (Eisenhardt, Martin 2000; Teece et al. 1997) bei vertingos informacijos dalijimąsi ir koordinavimą (Grant 1996a, 1996b). Todèl neatsitiktinai laikomasi nuomonès, kad šie teoriniai požiūriai tiek individualiai ir tiesiogiai lyginant vieną su kitu tapo pagrindu daugeliui mokslinių tyrimų, dariusių ịtaką strateginio valdymo disciplinos pažangai (Armstrong et al. 2009).

\section{Ilgalaikio konkurencinio pranašumo egzistavimo prielaidos}

Pažymètina, kad pradejjus formuotis konkurencinio pranašumo koncepcijai, tyrimų dėmesys sutelktas ị tai, kaip strateginiai įmonès sprendimai turètų padeti igyti ir išlaikyti konkurencinį pranašumą ilgalaikeje perspektyvoje. Todèl toliau tikslinga aptarti pagrindines mokslinių tyrimų kryp- 
tis, kurių pozicija - ilgalaikio konkurencinio pranašumo egzistavimas ir formavimas.

Sandorių sąnaudų teorija turëjo reikšmingą itaką analizuojant konkurencinio pranašumo priežastis. Coase pasiūlyta teorema ịrodo, kad egzistuoja sandorių ir tarpininkavimo sąnaudos. Todèl tyrimai, demesį koncentravę $\dot{t}$ sandorių ir tarpininkavimo sąnaudų minimizavimą, leidžia teigti, kad sandorių sąnaudų mažinimas sukuria strategines galimybes imonei ir yra tiesiogiai siejamas su ilgalaikiu konkurenciniu pranašumu (Foss K., Foss N. J. 2005).

Kita tyrimų grupè dèmesį koncentravo ị îvairias specifines pozicinio konkurencinio pranašumo formas, kurios iš esmès apima išskirtinę konkurencinę poziciją dèl patrauklios pramonès šakos struktūros (pvz., oligopolinėse rinkose), pranašumą dèl heterogeniškumo pramonès šakos viduje bei pranašumą dèl sukurtų ilgalaikių ryšių su pirkejais, tiekejjais ar konkurentais. Porter $(1980,1985)$ darbai leido išskirti sąlygas, kuriomis viena ar kita pramonès šaka tampa patrauklesnè neatsižvelgiant ị ịmonès, veikiančios toje pramonès šakoje, rezultatus. Pramonès šakos patrauklumui vertinti pasitelkiamas klasikinis penkių konkurencinių jègu modelis, leidžiantis tvirtinti, kad įmonès, veikiančios pramonès šakoje, pasižyminčioje didele konkurencija, aukšta pirkejų ir tiekèjų derybine galia, žemais įejimo barjerais bei didele pakaitalų grèsme, pasiekia žemesnius rezultatus.

Kita vertus, imta kelti klausimus dèl kitų veiksnių, kurie lemia konkurencini pranašumą (Korsakienè 2004; Ginevičius, Korsakienė 2005). Mokslininkų dėmesys nukrypo ị įmonès gebejjimus keistis, o ne užimti poziciją rinkoje ir suformavo prielaidas tolesniam ištekliais pagrịsto požiūrio formavimuisi.

Fundamentalia ištekliais pagrịsto konkurencinio pranašumo požiūrio idejja laikoma tai, kad įmonè turi sutelkti dèmesị ị savo išteklių ir gebejjimų tobulinimą, kad užsitikrintų konkurencini pranašumą neapibrěžtoje aplinkoje (Barney 2001). Šis požiūris dèmesị sutelkia ị vidinę įmonès aplinką bei papildo tradiciškai teikiamą dèmesį pramonès šakos struktūrai ir strateginiam pozicionavimui pramonès šakoje kaip pagrindiniams konkurencinio pranašumo veiksniams (Eisenhardt, Martin 2000).

İmonès turimi ištekliai, leidžiantys produktyviai kurti produktus ar paslaugas, efektyviai juos pristatyti rinkai ir kurti vertę vartotojui, yra tiek materialūs, tiek nematerialūs. Vis deltto argumentuojama, kad konkurencini pranašumą pirmiausia lemia vertingi ịmonès ištekliai, tokie kaip kolektyviniai gebejimai ir kompetencijos. Mokslinejje literatūroje diskutuojama apie tai, kad ịmonès ištekliai ir gebejjimai, kurių negalima įsigyti laisvojoje rinkoje, padeda užtikrinti ekonominę naudą, todèl jei konkurentai negali savo veiksmais šios naudos užsitikrinti, ji tampa ilgalaikiu konkurenciniu pranašumu. Ištekliais pagrịsto konkurencinio pranašumo požiūrio šalininkai tvirtina, kad unikalūs ištekliai yra tiesiogiai susiję su aukštesniais ịmonès rezultatais. Tai reiškia, kad ekonominę rentą generuoja unikalūs, sunkiai imituojami ir nemobilūs ištekliai. Šią teoriją plètojusių autorių nuomone, tarp konkurencinio pranašumo ir rezultatų egzistuoja tiesioginis ryšys, o įmone, turinti vertingų, retų ir sunkiai kopijuojamų išteklių, garantuotai užsitikrina aukštesnius rezultatus. Savo ruožtu ištekliais pagrisstas požiūris paneigè nuomonę, kad įmonès galimybès ir pavojai turètų būti vertinami gaminamo produkto ar teikiamos paslaugos atžvilgiu (Priem 2001). Kita vertus, siekiant užtikrinti optimalų i̇monés augimą, reikia ne tik tinkamai subalansuoti turimus išteklius, bet ir sukurti naujus.

Išskirtina įmonès gebėjimų, t. y. i̇monès pajëgumo paskirstyti išteklius, sąmoningai integruojant taip, kad būtų pasiektas užsibrežtas tikslas, reikšmė. Atkreiptinas dèmesys, kad kai kuriais atvejais įmonès gebèjimai yra išlavinami specifiniam procesui, o kitais - gebejimai yra bendriau pritaikomi. Tuo atveju, kai turima kompetencija yra išplitusi visoje i̇monèje, o ji turi nusistovejjusią tvarką, leidžiančią gauti ir koordinuoti informaciją, gebejimai tampa organizacijos bruožu. Daugeliu atvejų organizacinius gebėjimus lemia atskirų individų žinios ir gebejiimai. Tačiau dar didesnè svarba tenka organizacinei tvarkai ir hierarchijai, nustatančiai formalią valdžią, sukurtos formalios procedūros ir neformalios taisyklès, leidžiančios atlikti kompleksines užduotis.

Vis dèlto ištekliais pagrịsto konkurencinio pranašumo požiūrio apribojimu laikytinas jo taikymas dinamiškose rinkose, kuriose sunku paaiškinti, kodèl kai kurios įmonès turi konkurencinị pranašumą greitų ir sunkiai nuspẻjamų pokyčių metu. Tokiose rinkose i̇ greitai besikeičiančios aplinkos pokyčius reaguoti padeda dinaminiai gebejjimai, padedantys vadovams integruoti, sukurti ir naujai konfigūruoti turimus išteklius. Todèl atliekant mokslinius tyrimus, kurių esmé - gebèjimo perkonfigūruoti išteklius ị naujus strategiškai vertingus derinius analizè, dèmesys telkiamas i dinaminius gebëjimus (Eisenhardt, Martin 2000). Šie gebẻjimai apima daug gerai žinomų procesų, tokių kaip aljansų kūrimas, produktų kūrimas ir strateginių sprendimų priėmimas. Tvirtinama, kad konkurencinị pranašumą lemia ne patys gebẻjimai, bet jų sukuriami išteklių deriniai. Todèl dinaminiai gebejimai yra būtina, bet nepakankama sąlyga konkurenciniam pranašumui. Be to, tvirtinama, kad dinaminių gebejjimų koncepcija nèra tautologinè ar neaiški, kaip ją dažnai kritikuoja kiti mokslininkai (Priem 2001). Kita vertus, gebejimai, pasireiškiantys efektyviausiose įmonèse, tampa „gerąja praktika", todèl jiems būdingas didesnis homogeniškumas ir pakeičiamumas tarp įmonių. Itin dinamiškose rinkose dinaminiai gebejimai yra paprasti, eksperimentiniai, nestabilūs procesai, kai, siekiant sukurti nenuspejjamą rezultatą, kuriamos naujos žinios.

Mokslininkų nuomone, ištekliais pagrịsta teorija akivaizdžiai plètojama keliomis kryptimis, t. y. išsiskiria ištekliais pagrịstas požiūris ir žiniomis pagrịstas požiūris. Pastarąji plètojusių autorių nuomonès išsiskiria ị dvi grupes, 
t. y. tvirtinama, kad žinios yra pats svarbiausias įmonès išteklius arba adaptuojama daugiau pliuralistinè epistemologija, turinti socialinio konstruktyvizmo užuominų (Acedo et al. 2006). Žiniomis pagrịstas požiūris laikosi nuostatos, kad žinios yra išskirtinis įmonès išteklius ir organizaciniai gebejjimai apima ịvairių žinių rūšių ir formų integraciją. Procesai, kuriuos pasitelkusios įmonès integruoja specializuotas žinias, yra esminiai jų konkurenciniam pranašumui igyti ir išlaikyti (Grant 1996a). Tad tvirtinama, kad pranašumą lemia ne pačios žinios, bet žinių integracija. Iš esmès remiamasi tokiomis prielaidomis: 1) specializuotas žinias turi individai, o jie gali judetti tarp įmonių; 2) renta, kurią generuoja specializuotos žinios, yra daugiau priskiriama individams, o ne įmonei. Su nuosavybe siejamos žinios (pvz., patentai, autorių teisès ir pan.) greitai nuvertèja dèl senejjimo ir imitacijos. Todèl pramonès šakose, kurioms būdinga technologijų kaita, ilgalaikio konkurencinio pranašumo priežastimi laikoma ne su nuosavybe siejamos žinios, bet technologiniai gebejjimai, kurie padeda sugeneruoti naujas žinias. Išskirtinos trys žinių integravimo savybès siejamos su konkurenciniu pranašumu: integravimo efektyvumas, integravimo mastas ir integravimo lankstumas.

Moksliniai tyrimai, analizuojantys organizacijų ryšius, suformavo prielaidas ryšiais pagrịstam požiūriui formuotis. Teigiama, kad įmonès pranašumas siejamas su turimu pranašumu sukurtame ryšių su kitomis organizacijomis tinkle (Dyer, Singh 1998). Imonė gali sukurti vertingus išteklius valdydama ryšius su tiekejjais, klientais, vyriausybinèmis organizacijomis ar universitetais. Todèl konkurencinis pranašumas igyjamas ir išlaikomas įsigyjant svarbiausius išteklius už konkrečios įmonès ribų. Tai reiškia, kad konkurencija tarp individualių imonių tampa mažiau universali, nes tarpusavyje daugiau konkuruoja sajungininkai, sudarantys tinklinius ryšius. İmonès gali unikaliai derinti savo išteklius už organizacinių ribų, kad igytų pranašumą prieš konkurentus. Todèl išskirtiniai ryšiai gali būti santykinès rentos ir konkurencinio pranašumo priežastis.

\section{Trumpalaikio konkurencinio pranašumo egzistavimo prielaidos}

Pastaruoju metu mokslineje literatūroje imta diskutuoti, kad konkurencinis pranašumas yra retas, o jo trukmè iš esmès mažèja (Ruefli, Wiggnins 2003). Tokị požiūrị suformavo tokie veiksniai, kaip technologijų pokyčiai, globalizacija, pramonès šakų konvergencija, agresyvi konkurencinè elgsena, vyriausybių skatinama privatizacija, subsidijos, besivystančių šalių (Kinijos ir Indijos) pozicijos stiprejjimas, globalus politinis nestabilumas ir pan. Mokslinè literatūra, analizuojanti strategijas, sudarančias prielaidas siekti trumpalaikio konkurencinio pranašumo, paprastai išskiria aplinkos veiksnius, dèl kuriụ tikètina pranašumas bus laikinas. Tokiu būdu išsiskiria naujos rinkos, kurioms būdingas didesnis neapibrèžtumas ir intensyvi konkuren- cija. Tvirtinama, kad nestabilumas sukuria greitai besikeičiančias galimybes, kurios sudaro prielaidas trumpalaikiam pranašumui plètotis (Chen et al. 2010). Kita vertus, dèmesys sutelkiamas ị greitų ir dažnų konkurencinių veiksmų poveikị įmonių rezultatams arba keliamas klausimas - kodèl vienos įmonès imasi greitų konkurencinių veiksmų, o kitos ne, ir tuo tikslu pateikiami ịvairūs motyvai.

Mokslininkų nuomone, konkurencinị pranašumą lemiantys veiksniai yra kompleksiškesni, nei manyta, todèl stiprios įmonès pusès nèra vieninteliai konkurencini pranašumą lemiantys veiksniai, t. y. i̇monès silpnos pusès sąveikauja su stipriomis apribodamos stipriujjų teikiamą pranašumą (Sirmon et al. 2010). Diskutuojama apie tai, kad itin svarbu identifikuoti, kiek pačios įmonès sprendimai, konkurenciniai veiksmai ir elgsena neigiamai veikia konkurencinį pranašumą ir kas motyvuoja tokią įmonių elgseną (D’Aveni et al. 2010). Antai Chen et al. (2010) išskiria itin agresyvius veiksmus kaip aukščiausio lygio vadovų komandos savybę.

Kita vertus, svarbiais laikomi ir egzogeniniai, trumpalaikị konkurencinị pranašumą lemiantys veiksniai, skatinantys analizuoti pramonès šakos struktūrą ir ribas. Keliami klausimai - kaip pramonės šakų konvergencija ir konkuruojantys tokių šakų verslo modeliai daro ịtaką pranašumo praradimui, kokios, t. y. kontroliuojamos ar nekontroliuojamos, priežastys yra svarbesnès.

Atlikti tyrimai rodo, kad ekonominių ir kitų institucijų modernizavimas sudare trumpalaikio konkurencinio pranašumo prielaidas analizuotose besivystančiose šalyse, t. y. jose mažèjo ị institucijas orientuotų strategijų svarba, nyko pirminiai, konkurencinį pranašumą lemiantys veiksniai (Hermelo, Vassolo 2010). Kitaip tariant, institucijų modernizavimas iš esmès sudare prielaidas nunykti specifinèms žinioms ir gebejjimams, kurie įmonèms reikalingi nepakankamai išvystytų institucijų sąlygomis, o įmonès tampa labiau priklausomos nuo kitų veiksnių, tokių kaip technologija ar pozicionavimas rinkoje.

Pažymètina, kad rinkos ekonomikoje institucijos vaidina reikšmingą vaidmenį užtikrindamos efektyvų rinkos mechanizmo funkcionavimą taip, kad įmonès ir individai, sudarant rinkos sandorius, nepatirtų per didelių sąnaudų ar rizikos (Meyer et al. 2009). Paprastai institucijos apibūdinamos kaip reguliuojančios, normatyvinès, kognityvinès struktūros ir veiklos, kurios užtikrina stabilumą ir socialinès elgsenos prasmę (Scott 1995). Todèl plačiąja prasme institucijos klasifikuojamos $\mathfrak{i}$ formalias ir neformalias. Formaliomis institucijomis laikoma teisine sistema ir jos stiprinimas, nuosavybès teisès, informacinès sistemos ir reguliavimas. Neformalioms institucijoms priskirtinos etikos normos, požiūris ị verslumą ir pan. Išsivysčiusios ekonomikos šalyse, kuriose institucijos yra stiprios, jų vaidmuo nors ir laikomas esminiu, tačiau praktiškai sunkiai pastebimas. Besivystančios ekonomikos šalyse palaikančių institucijų nèra arba jos funkcionuoja netinkamai. 
Pažymètina, kad vadovai ir įmonès siekia savo tikslų ir priima strateginius sprendimus, atsižvelgdami ị instituciju sistemos apribojimus. Kita vertus, kai formalios institucijos nefunkcionuoja, didesnị vaidmenį vaidina neformalios institucijos, kurios padeda sumažinti neapibrèžtumą. Besivystančios ekonomikos šalyse įmonės vienu metu susiduria ir su ekspropriacijos rizika, ir su galimybe igyvendinti netradicines, su rinka nesusijusias strategijas. Todèl nepakankamai išvystytos institucijos sumažina konkurenciją ir imitavimą rinkoje, taip formuodamos sąlygas trumpalaikiam konkurenciniam pranašumui. Be to, nepakankamai išvystytos institucijos sudaro sąlygas netradiciniais būdais koncentruoti nuosavybę ir riboja pramonès šakų atsinaujinimą.

Mokslininkų grupè (Lee et al. 2010), analizavusi nepriklausomus programinės ịrangos pardavejus, sieke paaiškinti, kaip ir kodèl turimi dinaminiai gebejimai, kurių reikia produkto rinkos papildiniams valdyti, sudaro i̇monems sąlygas išlaikyti ir pagerinti rezultatus. Pažymètina, kad programinès įrangos gamintojų rinkoje produktai papildo vienas kitą, o pirkejjai prioritetą teikia produktų papildinių sistemai. Anot autorių, dinaminiai gebejjimai sudaro galimybes imonei nuolat kontroliuoti produktų papildinių rinkų tinklą ir identifikuoti tas produkto rinkas, kurios laiko atžvilgiu tampa silpniau ar stipriau papildančios. Antra, gebejjimai sudaro prielaidas įmonėms reaguoti ị pokyčius ir sukurti stipriau vienas kitą papildančiu produktų portfelį, kuris užima geresnę poziciją rinkoje. Iš esmès dinaminiai gebẻjimai padeda įmonei perkonfigūruoti išteklių paskirstymą savo produkto portfelyje, išskiriant tas produkto rinkas, kurios formuojasi kaip stipriai papildančios. Be to, dinaminiai gebejjimai sudaro prielaidas ieiti į naujas, stipriai papildančių produktų rinkas, kurios sustiprina bendrą įmonès papildančių produktų portfelio poziciją pramonès šakoje. Tokiu būdu turèdama bendrus dinaminius rinkos suvokimo ir reakcijos gebejjimus, įmoné gali geriau plètoti savo veiklą besikeičiančių produktų papildinių rinkoje, pagerinti rezultatus tų i̇monių, kurių gebejjimai yra silpnesni, keisti rezultatų vertinimą pramonès šakoje ir sukelti konkurentų atsakomuosius veiksmus. Iš esmès laikomasi nuostatos, kad dinaminiai rinkos suvokimo ir reakcijos gebejjimai gali intensyvinti konkurenciją pramonès šakoje.

\section{Konkurencinis pranašumas ir internacionalizacija}

Imonei augant formuojasi prielaidos igyvendinti internacionalizaciją, todèl internacionalizacijos ir augimo koncepcijos dažnai laikomos tarpusavyje susijusiomis (Buckley, Ghauri 1993). Kita vertus, mokslininkų teigimu, „internacionalizacijai būdingi specifiniai bruožai ir galima išskirti augimo savo šalies ir augimo tarptautinèse rinkose skirtumus“ (Ruzzier et al. 2006). Neatsitiktinai mokslinejje literatūroje keliamas klausimas - kodèl įmonès plečia veiklą i užsienio rinkas ir siekiama identifikuoti internacionalizaciją skati- nančius veiksnius bei formas (Korsakienė, Baranauskienè 2011; Korsakienė, Tvaronavičienè 2012). Vis dèlto, pasirinkusios internacionalizacijos strategiją, ¿̇monès skiriasi savo rezultatais. Todèl tikslinga kelti klausimą - kodèl vienos imonès yra sèkmingesnès už kitas tarptautinèse rinkose - ir nagrinèti konkurencinio pranašumo, internacionalizacijos ir prioritetinių strateginių sprendimų sąsajas (žr. lentelę).

Tradiciniai tarptautinio verslo tyrimai buvo siejami su sandorių sąnaudų teorija, nes įmonès plètra ị užsienio rinkas neatsiejama nuo papildomų sąnaudų. Remdamasi sandorių sąnaudų teorija, įmonè kiekvienai savo vykdomai veiklai pasirenka mažiausiomis sąnaudomis pasižyminčią rinką ir ją didina plèsdama tarpusavyje susijusias veiklas, kurias kontroliuoja iki internacionalizacijos, nauda yra didesnè už patiriamas sąnaudas.

Mokslininkų darbuose dėmesys telkiamas ir ị investuojančią įmonę, turinčią konkurencinị pranašumą prieš savo užsienio rinkos konkurentus bei plètojama monopolistinio pranašumo teorija (Barclay 2000). Pavyzdžiui, tvirtinama, kad monopolistinio pranašumo priežastimi gali būti produkto rinka (produkto diferenciacija, išskirtiniai rinkodaros ir paskirstymo gebëjimai), veiksnių rinka (išskirtinis priejimas prie kapitalo, ribotų technologijų ir išskirtiniai vadybiniai gebẻjimai) bei gebẻjimas igyvendinti vertikalią ir horizontalią integraciją. Vis dèlto laikomasi pozicijos, kad tiesioginès užsienio investicijos dažniausios pramonès šakose, pasižyminčiose oligopolinei rinkai būdinga struktūra, o horizontaliai integruotos įmonès turi unikalesnius išteklius nei užsienio rinkos konkurentai.

Kita vertus, tarptautinị verslą analizavę mokslininkai, pirmieji adaptavę sandorių sąnaudų ekonomikos požiūrị, vèliau prioritetą èmé teikti ištekliais pagrịstam požiūriui (Peng 2001). Tvirtinama, kad, remiantis ištekliais pagrịstu požiūriu, internacionalizacija laikytina tarptautinei veiklai svarbių ir reikalingų išteklių mobilizavimo, akumuliavimo ir plètros procesu. Teigiama, kad tarptautinių įmonių padaliniai užsienio rinkose turi turèti specifini konkurencini pranašumą, kurị lemia administracinis paveldas, organizacinès praktikos ir derybinè galia. Kita vertus, žmogiškieji ištekliai siejami su specifiniu įmonès pranašumu, todèl ištekliais pagrịstas požiūris akivaizdžiai paveike tarptautinị strategini žmogiškụjų išteklių valdymą, paskatindamas mokslininkus koncentruoti tyrimus tokiais lygmenimis, kaip pagrindinè įmoné, padaliniai ir darbuotojai. Ištekliais pagrịstas požiūris leido ieškoti sąsajų tarp išteklių ir visų diversifikacijos formų, todèl daugelyje mokslinių tyrimų tarptautinè diversifikacija (Peng 2001) analizuota laikantis nuomonès, kad produkto diversifikacijos patirtis formuoja vadybinius gebėjimus, leidžiančius efektyviau plètoti tarptautinę diversifikacijos strategiją.

İmonès gebejjimas įeiti į užsienio rinkas siejamas su jos akumuliuotais materialiais ir nematerialiais ištekliais. Tai reiškia, kad įmonès, turinčios vertingų, retų ir sunkiai nukopijuojamų išteklių, turi konkurencinį pranašumą ne tik vie- 
Lentelè. Konkurencinio pranašumo, internacionalizacijos teorijų ir prioritetinių strateginių sprendimų sąsajos

Table. Interrelationships between competitive advantage, internationalization theories and priority strategic decisions

\begin{tabular}{|c|c|c|c|c|c|}
\hline $\begin{array}{c}\text { Konkurencinis } \\
\text { pranašumas }\end{array}$ & $\begin{array}{l}\text { Tyrimų } \\
\text { kryptys }\end{array}$ & Autoriai & $\begin{array}{l}\text { Konkurencinị } \\
\text { pranašumą } \\
\text { lemiantys } \\
\text { veiksniai }\end{array}$ & $\begin{array}{c}\text { Ryšys su } \\
\text { internacionalizacijos } \\
\text { teorijomis }\end{array}$ & $\begin{array}{l}\text { Prioritetiniai } \\
\text { strateginiai } \\
\text { sprendimai }\end{array}$ \\
\hline \multirow[t]{6}{*}{ Ilgalaikis } & $\begin{array}{l}\text { Sandorių ir } \\
\text { tarpininkavimo } \\
\text { sąnaudų teorija }\end{array}$ & $\begin{array}{l}\text { Coase 1937; } \\
\text { Jensen, } \\
\text { Meckling } \\
\text { 1976; } \\
\text { Williamson } \\
\text { 1975; } 1985\end{array}$ & $\begin{array}{l}\text { Sandorių ir } \\
\text { tarpininkavimo } \\
\text { sąnaudos }\end{array}$ & $\begin{array}{l}\text { Teigiamas. } \\
\text { Pasirenkama mažiausiomis } \\
\text { sąnaudomis pasižyminti } \\
\text { rinka, o augimas vyksta } \\
\text { iki internacionalizacijos, } \\
\text { nauda didesnė už } \\
\text { patiriamas sąnaudas }\end{array}$ & $\begin{array}{l}\text { Sandorių ir } \\
\text { tarpininkavimo } \\
\text { sąnaudų } \\
\text { minimizavimas }\end{array}$ \\
\hline & $\begin{array}{l}\text { Pozicinis } \\
\text { konkurencinis } \\
\text { pranašumas }\end{array}$ & $\begin{array}{l}\text { Bain 1956, } \\
\text { 1959; Porter } \\
1980,1985\end{array}$ & $\begin{array}{l}\text { Patraukli } \\
\text { pramonès šakos } \\
\text { struktūra, } \\
\text { heterogeniškumas } \\
\text { pramonès šakos } \\
\text { viduje, ryšiai su } \\
\text { pirkejais, tiekejais } \\
\text { ar konkurentais } \\
\end{array}$ & $\begin{array}{l}\text { Teigiamas. } \\
\text { İmonès linkusios i } \\
\text { internacionalizaciją, jei } \\
\text { gali išnaudoti savo turimą } \\
\text { pranašumą užsienio } \\
\text { rinkose kuo mažiausiomis } \\
\text { sąnaudomis }\end{array}$ & $\begin{array}{l}\text { Pramonès šakos } \\
\text { pasirinkimas } \\
\text { ir strateginis } \\
\text { pozicionavimas } \\
\text { šakos viduje }\end{array}$ \\
\hline & $\begin{array}{l}\text { Ištekliais } \\
\text { pagrịstas } \\
\text { konkurencinis } \\
\text { pranašumas }\end{array}$ & $\begin{array}{l}\text { Amit, } \\
\text { Schoemaker } \\
\text { 1993; Barney } \\
\text { 1986, 1991; } \\
\text { Peteraf 1993; } \\
\text { Wernerfelt } \\
1984\end{array}$ & $\begin{array}{l}\text { Vertingi, reti } \\
\text { ir sunkiai } \\
\text { kopijuojami } \\
\text { ištekliai }\end{array}$ & $\begin{array}{l}\text { Teigiamas. } \\
\text { Imonès, turinčios unikalius } \\
\text { išteklių ir kompetencijų } \\
\text { derinius, daugiau linkusios } \\
\text { ị internacionalizaciją }\end{array}$ & $\begin{array}{l}\text { Tinkamai } \\
\text { subalansuoti } \\
\text { esami ištekliai } \\
\text { ir gebejimai bei } \\
\text { kuriami nauji }\end{array}$ \\
\hline & & $\begin{array}{l}\text { Eisenhardt, } \\
\text { Martin 2000; } \\
\text { Teece et al. } \\
1997\end{array}$ & $\begin{array}{l}\text { Gebejjimas naujai } \\
\text { konfigūruoti } \\
\text { išteklius ị naujus } \\
\text { strategiškai } \\
\text { vertingus derinius }\end{array}$ & & \\
\hline & $\begin{array}{l}\text { Žiniomis } \\
\text { pagrịstas } \\
\text { konkurencinis } \\
\text { pranašumas }\end{array}$ & $\begin{array}{l}\text { Grant 1996a, } \\
1996 b\end{array}$ & $\begin{array}{l}\text { Ivairių žinių } \\
\text { rūšių ir formų } \\
\text { integracija }\end{array}$ & $\begin{array}{l}\text { Teigiamas. } \\
\text { „Globaliomis gimusios“ } \\
\text { immonės užsitikrina } \\
\text { konkurencinị pranašumą } \\
\text { užsienio rinkose, } \\
\text { pritaikydamos žiniomis } \\
\text { pagrịstus išteklius }\end{array}$ & $\begin{array}{l}\text { Žinių integravimo } \\
\text { efektyvumas, } \\
\text { integravimo } \\
\text { mastas ir } \\
\text { integravimo } \\
\text { lankstumas }\end{array}$ \\
\hline & $\begin{array}{l}\text { Ryšiais } \\
\text { pagrịstas } \\
\text { požiūris }\end{array}$ & $\begin{array}{l}\text { Dyer, Singh } \\
1998\end{array}$ & $\begin{array}{l}\text { Išskirtiniai } \\
\text { ryšiai kuriami už } \\
\text { įmonès ribų }\end{array}$ & $\begin{array}{l}\text { Teigiamas. } \\
\text { Organizacijų } \\
\text { bendradarbiavimo ryšiai, } \\
\text { suteikiantys priejimą prie } \\
\text { specifinių dèl tinklaveikos } \\
\text { sukurtų išteklių užtikrina } \\
\text { konkurencinị pranašumą }\end{array}$ & $\begin{array}{l}\text { Išskirtinių ryšių } \\
\text { kūrimas }\end{array}$ \\
\hline \multirow[t]{2}{*}{ Trumpalaikis } & $\begin{array}{l}\text { Ištekliais } \\
\text { pagrịstas } \\
\text { konkurencinis } \\
\text { pranašumas }\end{array}$ & $\begin{array}{l}\text { Lee et al. } \\
2010\end{array}$ & $\begin{array}{l}\text { Dinaminiai } \\
\text { gebejjimai, } \\
\text { padedantys } \\
\text { perkonfigūruoti } \\
\text { išteklių } \\
\text { paskirstymą }\end{array}$ & $\begin{array}{l}\text { Teigiamas. } \\
\text { Turinčios unikalius išteklių } \\
\text { ir kompetencijų derinius } \\
\text { ịmonès daugiau linkusios ị } \\
\text { internacionalizaciją }\end{array}$ & $\begin{array}{l}\text { Tinkamai } \\
\text { subalansuoti } \\
\text { esami ištekliai } \\
\text { ir gebejimai bei } \\
\text { kuriami nauji }\end{array}$ \\
\hline & $\begin{array}{l}\text { Institucijų } \\
\text { teorija }\end{array}$ & $\begin{array}{l}\text { Hermelo, } \\
\text { Vassolo } 2010\end{array}$ & $\begin{array}{l}\text { Nepakankamai } \\
\text { išvystytos } \\
\text { institucijos, } \\
\text { mažinančios } \\
\text { konkurenciją ir } \\
\text { imitaciją rinkoje }\end{array}$ & $\begin{array}{l}\text { Teigiamas. } \\
\text { Institucijų sistema sudaro } \\
\text { palankesnes sąlygas } \\
\text { internacionalizacijai }\end{array}$ & $\begin{array}{l}\text { I institucijas } \\
\text { orientuoti } \\
\text { strateginiai } \\
\text { sprendimai }\end{array}$ \\
\hline
\end{tabular}


tos, bet ir tarptautinèse rinkose. Be to, tvirtinama, kad imonès, turinčios unikalius išteklių ir kompetencijų derinius, turi didesnị polinkị ị internacionalizaciją (Bloodgood et al. 1996). Kita vertus, laikomasi nuomonès, kad sprendimai, susiję su tarptautiniu verslu, yra priklausomi nuo unikaliu imonès kompetencijų, išplètotų laiko atžvilgiu.

Nemaža mokslinių tyrimų dalis, orientuota į internacionalizaciją, daugiausia dèmesio skyrè daugianacionalinèms imonèms. Kita vertus pastaraisiais metais daug dèmesio sulaukè smulkių ir vidutinių i̇monių (SVIt) internacionalizacija. Keliama prielaida, kad, pavyzdžiui, SVĮ nèra apsirūpinusios materialiais ištekliais. Toks fenomenas traktuojamas kaip „polinkis ị mažumą“ ir faktiškai SVĮ ištekliai yra apriboti iki nematerialių išteklių arba žinių (Chetty, Wilson 2003). Tokiu būdu žinių plètojimas, integracija ir perkèlimas laikytinas svarbiu internacionalizacijos strateginio valdymo aspektu. Mokydamosi iš užsienio rinkų patirties SVIt plètoja eksperimentines žinias, kurios gali būti perkeltos ị kitas užsienio rinkas (Blomstermo et al. 2004). Šis fenomenas itin būdingas "globaliomis gimusioms "ịmonems, t. y. nuo savo ìsteigimo pradžios siekiančioms aukštesnių veiklos rezultatų parduodant produktus užsienio rinkose ir pritaikant žiniomis pagrịstus išteklius. „Globaliomis gimusių“ imonių išskirtinės žinios sudaro prielaidas organizaciniams gebėjimams formuotis. Šių i̇monių konkurencinis pranašumas negali būti paaiškintas individualiais ištekliais, o tik ịvairių rūšių ir formų žiniomis. Neatsitiktinai teigiama, kad jei SVI gali generuoti konkurencinị pranašumą iš savo turimų žinių, jos gali internacionalizuotis kaip ir didelès įmonès (Gassman, Keupp 2007).

Tinklaveikos požiūriu internacionalizacijos procese išryškinamas ryšių ir santykių vaidmuo (Johanson, Matson 1993). Chetty ir Blankenburg-Holm (2000) teigimu, internacionalizacija vyksta: 1) sukuriant ryšius su partneriu užsienio rinkose; 2) stiprinant pasitikejjimą jau sukurtuose ryšių tinkluose; 3 ) integruojant savo poziciją ịvairių šalių ryšių tinkluose. Tad galima teigti, kad įmonès sèkmè naujose rinkose priklauso nuo jos pozicijos ryšių tinkluose ir santykių esamoje rinkoje. Pavyzdžiui, dauguma žiniomis pagrịstų, paslaugas teikiančių i̇monių pasiekia konkurencinị pranašumą, kurdamos abipusiškai naudingus ryšius su kitomis paslaugas teikiančiomis įmonemis.

Daugeliu mokslinių tyrimų patvirtinta prielaida, kad konkurencini pranašumą lemia mokymasis iš savo partnerių (Peng 2001). Pavyzdžiui, mokymasis iš parnerių laikomas vienu motyvuojančių veiksnių, skatinančių sudaryti strateginius aljansus. Organizacijų bendradarbiavimo ryšiai, i̇monei suteikiantys prièjimą prie specifinių dèl tinklaveikos sukurtų išteklių, ịvardijami kaip konkurencinio pranašumo priežastis.

Institucijų teorijos požiūriu galima daryti prielaidą, kad kai kurios besivystančios ekonomikos šalių įmonès priima internacionalizacijos sprendimus, tačiau jų realizavimo būdus be pramonès šakos ir išteklių apribojimų iš prigim- ties formuoja vietos ir tarptautinès institucijų sistemos. Tad besivystančios ekonomikos šalių institucijos gali sudaryti palankesnes sąlygas trumpalaikiam konkurenciniam pranašumui igyti ir tarptautinèse rinkose.

\section{Išvados}

Konkurencinio pranašumo tyrimai - neatsiejama strateginio valdymo tyrimų dalis, padariusi reikšmingą itaką strateginio valdymo disciplinos pažangai. Kita vertus, vykstanti mokslinè diskusija ne tik siekia paaiškinti, kokie veiksniai lemia ilgalaikị konkurencinį pranašumą, bet ir kokios prielaidos veikia trumpalaikị konkurencini pranašumą rinkoje. Šių priežasčių paieškas nusako šiuolaikinės konkurencinio pranašumo tyrimų kryptys, kurios pateiktos ir apibendrintos straipsnyje. Pažymètina, kad jau susiformavusių tyrimų krypčių ir atitinkamai konkurencinị pranašumą lemiančių veiksnių įvairovè suponuoja nuomonę, kad konkurencinio pranašumo priežastis tikslinga analizuoti remiantis ne vienu, o keliais skirtingais požiūriais.

Kita vertus, fundamentalių pokyčių, kuriuos lèmè globalizacija, naujos technologijos ir intensyvi konkurencija, kontekste daug dèmesio skiriama įmonès internacionalizacijai. Todèl tikslinga kelti klausimą - kodèl vienos ịmonès yra sèkmingesnès už kitas tarptautinèse rinkose - ir nagrinèti konkurencinio pranašumo, internacionalizacijos ir prioritetinių strateginių sprendimų sąsajas. Atkreiptinas dèmesys, kad mokslo darbuose ilgą laiką dominavę etapų, mokymosi, atsitiktinumų ir tinklaveikos požiūriai ị internacionalizaciją, vietą užleidžia integruoto turinio - proceso teorijoms, kurios laikytinos nauja įmonių internacionalizacijos tyrimų kryptimi. Pavyzdžiui, moksliniai tyrimai, analizavę SVİ internacionalizacijos fenomeną, integruoja etapų, tinklaveikos ir tiesioginių užsienio investicijų teorijas arba siūlo derinti procesų teorijas, inovacijų modelius, tinklaveikos teorijas, ištekliais pagrịstą požiūrị ir tarptautinę verslininkystę (Korsakiené, Tvaronavičienè 2012). Teigiamas konkurencinị pranašumą lemiančiu veiksnių ir internacionalizacijos teorijų ryšys sudaro prielaidas tolesniems moksliniams tyrimams. Vis dellto atkreiptinas dèmesys, kad šios sąsajos daugiau siejamos su internacionalizaciją skatinančiais veiksniais, todèl tikslinga būtų analizuoti ne tik sąryšius su internacionalizaciją ribojančiais veiksniais, bet ir internacionalizacijos būdais.

\section{Literatūra}

Acedo, F. J.; Barroso, C.; Galan, J. L. 2006. The resource-based theory: dissemination and main trends, Strategic Management Journal 27: 621-636. http://dx.doi.org/10.1002/smj.532

Amit, R.; Schoemaker, P. J. H. 1993. Strategic assets and organizational rent, Strategic Management Journal 14: 33-46. http://dx.doi.org/10.1002/smj.4250140105 
Armstrong, C. E.; Drnevich, P. L.; Newbert, S. L. 2009. Conversations about competitive advantage: a bibliographic analysis of the major research streams and their influence on the field, in Atlanta Competitive Advantage Conference 2009.

Bain, J. 1956. Barriers to New Competition. Cambridge, MA: Harvard University Press.

Bain, J. 1959. Industrial Organization. New York: Wiley.

Barclay, L. A. 2000. Foreign Direct Investment in Emerging Economies. Routledge. http://dx.doi.org/10.4324/9780203463116

Barney, J. B. 1986. Strategic factor markets: expectations, luck, and business strategy, Management Science 32: 1231-1241. http://dx.doi.org/10.1287/mnsc.32.10.1231

Barney, J. B. 1991. Firm resources and sustained competitive advantage, Journal of Management 17: 99-120. http://dx.doi.org/10.1177/014920639101700108

Barney, J. B. 2001. Resource-based theories of competitive advantage: a ten - year restrospective on the resource-based view, Journal of Management 27: 643-650.

Blomstermo, A.; Eriksson, K.; Sharma, D. 2004. Domestic activity and knowledge development in the internationalization process of firms, Journal of International Entrepreneurship 2(3): 239-258.

Bloodgood, J. M.; Sapienza, H. J.; Almeida, J. G. 1996. The internationalization of new high potentional U.S. ventures: antecedents and outcomes, Entrepreneurship Theory and Practice 20(4): 61-76.

Buckley, P. J.; Ghauri, P. N. 1993. Introduction and overview, in P. J. Buckley, P. N. Ghauri (Eds.). The Internationalization of the Firm. London: Academic Press, ix-xxi.

Chen, E. L.; Katila, R.; McDonald, R.; Eisanhardt, K. M. 2010. Life in the fast lane: origins of competitive interaction in new versus established markets, Strategic Management Journal 31(13): 1527-1547. http://dx.doi.org/10.1002/smj.894

Chetty, S. K.; Wilson, H. 2003. Collaborating with competitors to acquire resources, International Business Review 12(1): 61-81. http://dx.doi.org/10.1016/S0969-5931(02)00088-4

Chetty, S.; Blankenburg-Holm, D. 2000. Internationalization of small and medium-sized manufacturing firms: a network approach, International Business Review 9(1): 77-93. http://dx.doi.org/10.1016/S0969-5931(99)00030-X

Coase, R. H. 1937. The nature of the firm, Economica 4: 386-405. http://dx.doi.org/10.1111/j.1468-0335.1937.tb00002.x

D'Aveni, R. A.; Dagnino, G. B.; Smith, K. G. 2010. The age of temporary advantage, Strategic Management Journal 31: 1371-1385. http://dx.doi.org/10.1002/smj.897

Day, G. S.; Wensley, R. 1988. Assessing advantage: a framework for diagnosing competitive superiority, Journal of Marketing 52: 1-20. http://dx.doi.org/10.2307/1251261

Dyer, J. H.; Singh, H. 1998. The relational view: cooperative strategy and sources of interorganizational competitive advantage, The Academy of Management Review 23(4): 660-679.

Einserhardt, K. M.; Martin, J. A. 2000. Dynamic capabilities: what are they?, Strategic Management Journal 21: 1105-1121. http:// dx.doi.org/10.1002/1097-0266(200010/11)21:10/11<1105::AIDSMJ133>3.0.CO;2-E
Foss, K.; Foss, N. J. 2005. Resources and transaction costs: how property rights economics furthers the resource-based view, Strategic Management Journal 26: 541-553.

http://dx.doi.org/10.1002/smj.465

Gassmann, O.; Keupp, M. 2007. The competitive advantage of early and rapidly internationalising SMEs in biotechnology industry: a knowledge- based view, Journal of World Business 42: 350-366. http://dx.doi.org/10.1016/j.jwb.2007.04.006

Ginevičius, R.; Korsakienè, R. 2005. Exploration of strategy: objectives, competencies and competitive advantage, Journal of Business Economics and Management 6(1): 13-22.

Grant, R. M. 1996a. Prospering in dynamically - competitive environments: organizational capacity as knowledge Integration, Organization Science 7: 375-387. http://dx.doi.org/10.1287/orsc.7.4.375

Grant, R. M. 1996b. Toward a knowledge-based theory of the firm, Strategic Management Journal 17: 109-122.

Hermelo, F. D.; Vassolo, R. 2010. Institutional development and hypercompetition in emerging economies, Strategic Management Journal 31(13):1457-1473.

http://dx.doi.org/10.1002/smj.898

Jensen, M. C.; Meckling, W. H. 1976. Theory of the firm: managerial behaviour, agency costs and capital structure, Journal of Financial Economics 3: 305-360.

http://dx.doi.org/10.1016/0304-405X(76)90026-X

Johanson, J.; Mattsson, L. G. 1993. Internationalization in industrial systems - a network approach, strategies in global competition, in P. J. Buckley, P. N. Ghauri (Eds.). The Internationalization of the Firm: A Reader. London: Academic Press, 303-322.

Karnani, A. 1984. Generic competitive strategies - an analytical approach, Strategic Management Journal 6: 329-334.

Korsakiene, R. 2004. Determining competitive advantage : the analytic hierarchy process, Journal of Business Economics and Management 5(4): 205-215.

Korsakiene, R.; Baranauskienè, A. 2011. Factors impacting sustainable internationalization: a case of multinational company, Journal of Security and Sustainability Issues 1(1): 53-62.

Korsakienè, R.; Tvaronavičienè, M. 2012. The Internationalization of SMEs: an integrative approach, Journal of Business Economics and Management 13(2): 294-307. http://dx.doi.org/10.3846/16111699.2011.620138

Lee, Ch.; Venkatraman, N.; Tanriverdi, H.; Iyer, B. 2010. Complementarity based hypercompetition in the software industry: theory and empirical test, 1990-2002, Strategic Management Journal 31: 1431-1456. http://dx.doi.org/10.1002/smj.895

Meyer, K. E.; Estrin, S.; Bhaumik, S. K.; Peng, M. W. 2009. Institutions, resources and entry strategies in emerging economies, Strategic Management Journal 30: 61-80. http://dx.doi.org/10.1002/smj.720

Peng, M. W. 2001. The resource- based view and international business, Journal of Management 27: 803-829. http://dx.doi.org/10.1177/014920630102700611

Peteraf, M. A. 1993. The cornerstones of competitive advantage: a resource - based view, Strategic Management Journal 14: 179-191. http://dx.doi.org/10.1002/smj.4250140303 
Porter, M. E. 1980. Competitive Strategy. New York: The Free Press.

Porter, M. E. 1985. Competitive Advantage. New York: The Free Press.

Priem, R. L. 2001. Is the resource-based "View" a useful perspective for strategic management research?, Academy of Management Review 26(1): 22-40.

Ruefli, T. W.; Wiggins, R. R. 2003. Industry, corporate and segment effects and business performance: a non-parametric Approach, Strategic Management Journal 24(9): 861-879. http://dx.doi.org/10.1002/smj.350

Ruzzier, M.; Hisrich, R. D.; Antoncic, B. 2006. SME internationalization research: past, present and future, Journal of Small Business and Enterprise Development 13(4): 476-497. http://dx.doi.org/10.1108/14626000610705705
Scott, W. R. 1995. Institutions and Organizations. Thousand Oaks, CA: Sage.

Sirmon, D. G.; Hitt, M. A.; Arregle, J. L.; Campbell, J. T. 2010. The dynamic interplay of capability strengths and weaknessess: investigating the bases of temporary competitive advantage, Strategic Management Journal 31(13): 1386-1409. http://dx.doi.org/10.1002/smj.893

South, S. E. 1980. Competitive advantage: the cornerstone of strategic thinking, Journal of Business Strategy Spring: 15-22.

Teece, D. J.; Pisano, G.; Shuen, A. 1997. Dynamic capabilities and strategic management, Strategic Management Journal 18: 509-533. http://dx.doi.org/10.1002/(SICI)10970266(199708)18:7<509::AID-SMJ882>3.0.CO;2-Z

Wernerfelt, B. 1984. A resource - based view of the firm, Strategic Management Journal 5: 171-180.

Renata KORSAKIENĖ. PhD, works as Associate Professor at Vilnius Gediminas Technical University, Department of Enterprise Economics and Management. Her research interests involve: strategic management, innovation management and change management of organizations. 